Laboratory of Economics and Management Sant'Anna School of Advanced Studies

Piazza Martiri della Libertà, 33 - 56127 PISA (Italy)

Tel. +39-050-883-343 Fax +39-050-883-344

Email: lem@sssup.it Web Page: http://www.sssup.it/ LEM/

\title{
LEM
}

Working Paper Series

\section{Missing the Starting Gun? \\ Entry Timing Decisions into \\ New Market Niches}

\author{
Marco S. GIARRATANA*
}

*Universidad Carlos III, Madrid, Spain 


\title{
MISSING THE STARTING GUN ENTRY TIMING DECISIO NS INTO NEW MARKET NICHES
}

\author{
Marco S. Giarratana ${ }^{1}$ \\ Universidad Carlos III, Madrid, Spain
}

\begin{abstract}
This study analyzes incumbent entry timing decisions in new markets in the case of Encryption Software (ES). In ES first technological movers were slow to enter the downstream market, losing their initial advantages to the benefit of newcomers. This work tests the hypothesis that this wait-and-see strategy was an optimal choice compared to the assumption of inertia embedded in the decision process of potential entrants. We find that entry decision is not the outcome of firm rational balancing among different strategic variables, but it is more similar to a heuristic process that fails to accommodate the full logic of decision.
\end{abstract}

Keywords: Entry timing decision, first-mover advantages, inertia, software JEL: L89, L290, O33

\footnotetext{
${ }^{1}$ Department of Business Administration, Universidad Carlos III, Calle Madrid, 126, 28903 - Getafe, Madrid, Spain. E-mail : mgiarrat@emp.uc3m.es. Tel.: +34 919249608 Fax: +34 916249607
} 


\section{INTRODUCTION 2}

Can imitators take advantage of the knowledge developed by technology pioneers and by their eventual strategic mistakes?

In answering this question, entry timing takes central stage as one of the most important variables of firm choice, at least as well critical as the decision of "where" to enter. This represents an underestimated approach given that large part of the existing literature has focused on the relationship between incumbent competencies and the trajectories of firm diversification (see for a survey Silvermann, 1999), almost ignoring how entry timing decisions could affect this process.

In order to study incumbent entry process, we first highlight two essential regularities observed in many industries. One is that large established firms carry out the most important part of R\&D investments to explore new technological trajectories and to build a diversified technological portfolio. They also produce by far the largest part of world innovations and patents (Pavel and Pavitt, 1997). Moreover, especially in software, patents are increasingly held by large firms (Bessen and Hunt, 2003).

Second, by the same token, a wide collection of industry cases (Hendersons, 1993; Schnaars, 1994; Shane, 2001) shows how often incumbents that own the required technological and commercial assets prefer to adopt wait-and-see and catching-up strategies, leaving to new ventures the task to open new markets. In addition, empirical evidence (Christensen, 1997; Bhide, 2000) suggests that not only founders of innovative start-ups are often former employees of large established firms, but that they also shaped their projects exploiting "sleeping" resources of mature organisations.

Taken this viewpoint, the creation of new markets and the diffusion of innovations are generated by the interaction between the ability of late-comer incumbents in leapfrogging market pioneers and first mover advantages gained by first product developers that were imitators of the leading technology ${ }^{3}$ (Carroll et al., 1996). It is straightforward that incumbent entry timing decisions are at the foundations of the process, since they could explain how and when a new industry emerges and what organizations are the main actors in the different industry phases.

The aim of this work is to understand if, aware of these "rules of the game", incumbents take strategic entry decisions exploiting all their existing resources. Or, conversely, if firm entry decisions are more driven by "rule of the thumb" mechanisms that fail to take in account all the information available.

In so doing, we show how in the Encryption Software Industry (ESI), our case study, first technological movers were late to enter into downstream markets, leaving newcomers the opportunity to dominate the industry. Then, after reviewing the existing literature, we discuss the research hypotheses and test them with three econometric models. We find that incumbent entry timing decision in ESI is not the

\footnotetext{
${ }^{2}$ This paper could not be done without the suggestions and comments of Giovanni Dosi, Andrea Fosfuri, Alfonso Gambardella, Bronwyn Hall and Salvatore Torrisi. I also am grateful for comments to Ashish Arora, Carolina Castaldi, Fabrizio Cesaroni, Giorgio Fagiolo, Paola Giuri, Steven Klepper, Daniel Levinthal and Alessandra Luzzi. The paper improved greatly thanks also to discussions with Orry Ben-Porath at Check Point Software. An early version of this paper received the 2003 Young Economist Prize of Schumpeter Society. The usual disclaims apply.

3 This topic has also a straightforward importance in terms of firm strategic decisions and policy implications. In fact, a possible market failure situation is when the firms with the necessary technology do not want to open new product markets, while the firms aiming to exploit new market opportunities could not gain access to required technologies. At this regard the efficient development of a market for technology could help to avoid this market failure; see Arora et al., 2001.
} 
direct outcome of a process of long run decision on timing, but a "sub-product" of an entry-vs-no entry choice that firms tend to repeat.

This issue opens also the discussion on the rationality of large firm investments in wide-diversified knowledge inventories (Miller, 2002): is this really a rational strategy with expectations of long run returns, or are incumbents to some extent generating technological resources that other organisations will exploit?

\section{THE ENCRYPTION SOFTW ARE INDUSTRY}

Providing novel empirical evidence, ESI is an ideal case study, which includes all the issues we presented in the Introduction. ESI shows how first innovators could not (or do not want to) exploit all the technological competencies they created and to some respect, they could lose their initial advantage to the benefit of new comers. During the mid 1970s, the market opportunities arising from the military sector spurred established electronic firms to accumulate knowledge in Encryption Software Technology 4 .

Table 1 shows the most important firms for patents granted and cited in USPTO 380 class "Cryptology" between 1976 and 1992. Large ICT firms and university departments were the first technological movers.

\section{[Table 1 about here.]}

A previous study (Giarratana, 2004) gives evidence of the importance of mathematical algorithms and patents as protection tools in ESI, especially in USPTO class 380. A crypto algorithm is a procedure that takes the plain text data and transforms it into cipher text. This process could be reversed with a secret key (the usual password). The core of security products is the mathematical procedure that lies behind the encryption of data. Patents offer therefore a good protection mechanism against imitation and preservation of intellectual proprietary rights.

From the second half of the 1980s, the industry landscape has mostly changed. The development of the PC market and Internet gave rise to a demand for civilian purposes, introducing new market needs and products in the industry ${ }^{5}$. International Data Corporation ${ }^{6}$ evaluated the world market of ESI at 2.17 billion dollars in 1997 and 3.2 billion dollars in 1998, with an estimate of 4.4 billion dollars for 1999 .

Offering a wide array of products from the basic products of encryption to advanced security services, ESI could be now defined as an industry specialised in the design, market development and support of security software, solutions, and products that protect data and software on computers and networks.

The increased civilian demand has spurred a flow of firm entry since 1989, the year when the first product was released on the market. Figure 1 shows firm entry, exit and the number of firms on the market between 1989 and 2001. It is worth noticing that most part of the entry is by start-ups, and not by incumbent diversification.

[Figure 1 about here.]

\footnotetext{
${ }^{4}$ See Appendix A for more information about data collection procedures.

5 "Rising E-commerce will drive Growth for Security Software Companies", Business Week, April 4th, 2000 , p. 6.

6"Worldwide Internet Security Software Market to close in on 4.4 billion dollars in 1999", EDP Weekly's IT Monitor, 40(32), 1999, p. 18.
} 
Moreover, also in ESI, founders of most start-ups were former employees of large firms and university research departments (Giarratana, 2004).

However, if we look at the most important firms for patents granted in the period 1993-1999 (see Table 2), large established firms again played the major role ${ }^{7}$.

[Table 2 about here.]

Notwithstanding this evidence, in terms of market share, Hoover's data show that by 1998 the top 15 firms in ESI were all start-ups, accounting for about $43 \%$ of the total world market (Giarratana, 2004).

These top 15 start-ups were granted 88 patents in 380 USPTO class by 1999, with a total of 446 backward citations. Looking at the most important firms cited by these 88 patents, large ICT firms still remained in the leading positions. This highlights a technological dependence of start-up technology upon the knowledge created by large firms (see Table 3).

\section{[Table 3 about here.]}

Large ICT firms that were the first technological movers and the largest producers of patented inventions, entered into ESI with their own products in the last years of the 1990s, on average 5-6 years after the first successful products of start-ups. In particular, IBM in 1998 and H\&P in 1999 began to offer a broad range of software security products ${ }^{8}$.

The evidence presented strongly suggests that, in ESI as in other industries, mature organisations choose to enter only when the new market was consolidated, exploiting their commercial and downstream strength. This happened even when large firms were technological first-movers and main patentees of the core technology.

Widespread theoretical (Rubin, 1973; Teece et al.,1994) and empirical (Silverman, 1999; Montgomery, 1994) literature on diversification sustains the long term success of a resource based firm diversification, originated by economies of scope from firm knowledge base. If we follow this view, for most large technological first movers, ESI would have been a case of a coherent knowledge based diversification. The history of ESI leads us to investigate why large firms were so quick to enter the technological race, creating valuable competencies 20 years before the development of ESI. However, they lagged behind newcomers in the market for products. Note that if an incumbent potential entrant had been the ESI market leader at 1998, it would have increased its total revenues on average of about $6 \%$.

In particular, we are interested in understanding if the wait-and-see behaviour was a rational and conscious strategy or if large firms were affected by some sort of inertia. $\mathrm{ESI}$ is a classical case of a trade-off between the advantages of late entrants and first movers (Mueller, 1997). If start-ups have been able to achieve sound and not easily replicable first mover advantages, it could be the case that ESI will be dominated in the future by small-medium size specialised firms.

If first mover advantages are small compared to the technological and commercial strength of large established firms, ESI will be a good case study to understand the role played by new firms in the exploration of new technological fields and in the formation of new market niches that in the long run will be served by large firms.

\footnotetext{
${ }^{7}$ See Mowery et al., and Jaffe et al., for a comprehensive survey of patent citations.

8 "H\&P and IBM go head to head on Net Security", Unix and NT News, Feb. 1999, p. 14.
} 


\section{THE LITERATURE SURVE Y}

\section{The "rational" approach}

Many contributions show how incumbents are more likely to be followers than first movers into new product areas (Scherer, 1980; Schnaars, 1994). The decision not to be a first mover could be a rational decision of many large companies that prefer to adopt a strategy of waiting until new markets are large enough and customer preferences consolidated (Christensen, 1997).

Mitchell (Mitchell, 1991; 1989) points out that early entry could convey risks for large firms especially if new markets require their own specialised downstream assets that are difficult to build rapidly. While the time of entry is important in determining the survival probability of start-ups, incumbent survival rate is only affected by the time of entry of other incumbents.

Incumbents usually perform better in strategies of imitation and catching-up, once newcomers have tested new products and markets. An established firm will always be confident to compete easily against small start-ups, due to a scale effect. However, incumbents could be threatened when competitors of a similar dimension enter the market. Entry delays when market turbulence decreases allows large firms not to search their competitive advantages on short run disequilibria. The costs of imitation and late entry are usually evaluated lower then those originating from the uncertainties of new markets.

Moreover, mature organisations have low incentives to enter in new market niches because of the possibility of cannibalisation of their existing products. New goods may reduce sales of existing products (Klepper, 2001; Tushman and Anderson, 1986). For Aron and Lazear (1990) an incumbent entry decision must include the costs of lost revenues from sales of existing products when a new one is introduced. Incumbents tend to be reluctant to open up new markets and are induced to follow. Conservative strategies are the best strategies for most industry successful corporations that start competing in new markets until the number of existing competitors reaches a certain point. According to Cho et al. (1988), late entry for many firms may be the only realistic option given their competitive dynamics. Numerous established competence rich companies allow early movers to test the market and only when market signals are positive, they enter and compete. Numerous examples in various industries are available (Schnaars, 1994). Large companies have great opportunity costs in investing resources into risky markets, and they wait until market leaders emerge to learn and imitate from them (the socalled benchmarking strategy). In so doing, entry of large companies occurs when new industries and market characteristics become similar to those of existing market areas (Smith and Cooper, 1988).

Finally, Kats and Shapiro (1987) show that when a product could be easily imitated an incumbent will often benefit by delaying entry.

\section{The "inertia" approach}

A massive stream of heterogeneous literature discusses the relationship between economic decisions and general bounded rationality (Conlisk, 1986). To narrow the field of analysis, in this section we select only the works that focus on the problem of firm decisions and inertia. The aim is to compare the idea of rationality as the best 
behaviour given the perceived opportunities with a heuristic decision process that fail to accommodate the full logic of decision.

At this regard, Henderson and Clark (1990) highlight two levels of problems associated with large firm difficulties to cope with innovation breakthrough and market birth. One level refers to a cognitive part of large firm entry decisions. Large organisations could show inefficiencies during the phase of recognition and interpretation of the environment, a preliminary condition of any strategic actions or responses. In a seminal work on this aspect, Jelinek (1977) points out the possible rigidities that could originate in a complex organisation formed by highly specialised functions. These rigidities are mainly generated by the fact that organisations interpret their environment with a limited vision, because "they only see what they are programmed to perceive" (p. 21). By the same token, March (1988) suggests that firm moves are bounded more by decisions with respect to search then by decisions among alternatives, due to the narrow range of alternatives and consequences that firms could consider simultaneously. Authors (Barr, 1998; Grever and Taylor, 2000) study the links between the cognitive process of manager teams and the timing and content of strategic changes. Assuming that before the elaboration of any strategic actions, decision-takers should first mature the interpretation of a specific outcome, the interpretation of unfamiliar events is consistent with a common pattern of development that goes from vague to broad-based definitions, to detailed and specific impacts on the organisation itself (Baum and Wally, 2003). It follows that the process of interpretation is time consuming, preventing large organisations from responding until he stimulus is interpreted. Changes in activities are consistent and follow changes in interpretations, causing large organisations to prefer an adaptive behaviour compared to an anticipating one. Levinthal and March (1993) use the term "myopia" in assessing large firm problems with change and innovation. The authors depict firm learning as a unique mechanism to pursue the organisational rationality, optimising actions. However "learning has its own traps" (p. 97), for the reason that "problems that are not seen do not exist" (p. 99). Learning creates a simplified world and a specialised organisation. But this process involves a trade-off since strategies that allow short run survival tend to increase long term vulnerability. The authors cite three major constrains in the contribution of learning to organisational rationality: a) learning is directed more to short run events rather than long term ones; b) learning is often limited by the stock of competencies of firms, and it is in the strict sense local; c) learning does not tend to process and analyse failures, with an over evaluation of the successes. Along this view, Christensen (1997) highlights how large high performing companies, strongly tailored to existing consumer needs, find very difficult to invest resources in yet-to-be-formed markets. Analysing several industries, Christensen finds that incumbents fail to enter new markets, even if they have developed the required technology. "Finding new markets is a capability that firms exhibited once and then lost" (p. 24). The problem lies in the fact that most resources are absorbed in competing in actual markets, while new applications of existing competences are ignored since they do not create value in the existing environment. The application of firm rationality on future markets and customers is a costly process that industries produce when the profitability of existing markets is in danger. This view is similar with the one in Brock and Hommes' (1997): economic agents use costly rational tools only when there is high variance in the realized profits, while they prefer to use simple and cheap rules of behaviour (consolidated organisational routines) when prediction errors are small. Large firm errors in the presence of radical change are rooted in rational management, since managers 
apply their rational analysis to existing landscapes, even when creating new markets is significantly less risky and more rewarding than competing in established markets (Christensen, 1997).

The second level of inertia stressed by Henderson and Clark could be defined as a procedural inertia that makes mature hierarchies inadequate and slow in conducting business in new markets with high turbulence, even if the strategic decision speed is high. In the stream of literature focused on this aspect, several authors and several case studies (Dowell and Swaminathan, 2000; Henderson, 1993; Henderson and Clark, 1990; Bresnahan, 1985) illustrate how switching to new modes of learning and investing resources in new product architectures is costly for large established firms. Re-orienting organisations is a time consuming operation. Breaking previous linkages and re-designing channels of information flows could generate difficulties and problems inside organisations. Knowledge embedded in routines and channels that have guaranteed past competitive advantages, often become inert and difficult to change in the presence of new rules of competition. Direct interviews (Dougherthy and Heller, 1994) conducted with large firm employees involved in product innovation show how large mature firms might be too slack in learning and adapting to new environments. These scholars coin the concept of "barriers to innovation", referring to difficulties in fitting the activities of product innovation into the institutionalised routines of large firms. Because dynamic innovators need links to meet user needs, then they must coordinate the expertise of different functions within the firm, with firm strategy and resources. These links often do not fit into routinized actions in large firms. "Innovation do not fit into and it is not part of large firm organisations" (p.206). Studies in population ecology (Hannan and Freeman, 1984) indicate factors (goals, authority, core technologies and marketing strategies) that cause structural inertia in organisations. They consider learning and structural inertia in a dynamic context, where large organisations respond to the occurrences of change, but slowly. Inertia appears when the speed of reorganisation is much lower than the rate at which external conditions change. The authors interpret inertia as a consequence of selection, because firms more able to reproduce a structure with a close fit to the existing environment are those that will sustain the major costs in shifting paradigms. Complex organisations have slow response times not because they are slow in detecting opportunities, but because the process of adjustment takes longer. Dougherthy and Hardy (1996) stress how structure and strategies in mature organisations reinforce existing practices and became hostile to creativity. One of the main problems is to incorporate innovation as a component of the existing organisation and strategy, making resources available and providing the necessary collaboration of structures and processes (the so-called reframing process).

In other words, established hierarchies seem to be less efficient in managing innovation compared to new businesses that could more easily shift operations on arm-length transactions in the market. The presence of pre-existing practices, coordination procedures and specificities make it more difficult and time consuming to open new product markets. Reframing costs do not affect the process of decisionmaking, but only the operational procedures to perform innovation. Large organisations are not against innovation, but they make structurally innovation more costly to manage since they were configured according to different patterns tailored to specific environments.

Finally, Chesbrough (2000) draws attention to the inefficiencies of firm internal financial markets. The author stresses the inability of corporations to provide financial incentives that can be easily achieved by an independent start-up. Problems of 
adverse selection inside organisations show new opportunities as threatening to established businesses, making more difficult for new projects to compete for scarce corporate resources. In most corporations, management prefers to invest in the secure "cash cow" sectors rather then in projects that would gain financial returns in the long run.

\section{RESEARCH HYPOTHESES}

Literature (see Lieberman and Montgomery, 1988) assumes that there are two types of choice that a firm faces in the contest of entry: i) decision on "entry" versus "not entry" ii) decision on entry timing, given the entry. In a nutshell, the entry decision is a twofold process that account for the effective profitability of entering in new markets, and for the ways this profitability could be strategically improved through correct decisions on entry timing. In fact, factors affecting firm entry decision usually differ from those that explain firm performance in the long run (Gerosky, 1995; Teece et al., 1997; Audretsch, 1991; Klepper and Simons, 2000). Granted this point, efficient firms should evaluate first if entry is profitable, and then adjust entry timing according to their strategies. Thus, we hypothesize that with no inertia, firms choose whether or not to enter in a new market, and then, given the entry, the time of entry (e.g. early or late). In other words, firms look simultaneously at three possible decisions (not enter, enter early and enter late), selecting their best option. In this framework earlyentrants could count on market learning processes and first mover advantages, while latecomers, avoiding the turbulence and the uncertainty of the first periods of industry evolution, are confident of easily imitating the market leaders (Vanderwerf and Mahon, 1997; Lieberman and Montgomery, 1988; Mitchell, 1989; Levin et al, 1987).

Hypothesis 1a: With no inertia, incumbent firms separate the decision of entry ("entry" versus "not entry") from the decision of entry timing (early or late).

Conversely, suppose now to introduce firm inertia, assuming a firm myopia in the form of limited period foresight (Miller, 2002). With inertia, firm evaluation of entry profitability will inevitably merge with the decision of entry timing. In other words, there is no ex-ante decision of entry timing, given the strategic and organizational difficulties that firms suffer only for taking the decision of entry. Inertia does not provide room for using entry timing as a strategic variable. In fact, if we are dealing with a cognitive inertia, firms have to regain the time lost in recognizing the actual business opportunity. With procedural inertia, selecting the right entry timing is unfeasible given the firm rigidity in organizing the entry at different speeds.

Hypothesis 1b: With inertia, firms collapse the decision of "entry" and of "entry timing" in a unique decision.

The prospect of gaining competitive advantages with entry time fine-tuning indicates the existence of firm specific abilities in obtaining profits in targeted markets with different entry times. Probability to succeed in new markets with different entry choices represents a sort of firm specific asset designed to compete in multiple environments. It is clear-cut that given the targeted market, some organizations tend 
to perform better with a late entry avoiding early instability, while dher firms show high abilities in rushing into young turbulent industries.

According to the dynamic capabilities approach (Winter, 2003; Teece et al., 1997), firms are characterized by several inner features, part of which is "pre-determined" and in some sense "sticky" (for sake of simplicity, we label them A-variables) and part of which is more dynamic, competence grounded and aimed to affect performance in particular markets (B-variables). A-characteristics are less market-linked variables, stem from very old firm decisions and are more difficult to adjust in the short run. On the other side, firms could easily move B-variables that directly influence the performance in new markets. We could take the example of a US radio producer decision to enter in the emerging US television-receiver market ${ }^{9}$ during the $1940 \mathrm{~s}$. This radio producer could own particular technological expertises (e.g. a patented shadow mask tube technology) or have recently acquired some local distributor central for the television-receiver market. These are clearly B-variables. By contrast, if this potential entrant is an US firm (or European) and comes from the radio industry (or from other sectors) are attributes very near to our definition of A-variables. This difference is quite in line with Winter's (1987) distinction of "state" versus "control" strategic variables, that is "the distinction between aspects ... that are not subject to choice over a short time span and aspects that are" (p. 162).

Following this view and some ad-hoc literature (Carroll et al., 1996), the decision of entry (yes or not) should depend mostly by Avariables, while the decision of entry timing should be mainly influenced by firm B-attributes. This means that firm decision to enter (or not to enter) in a new market is influenced mainly by structured, stable firm characteristics, while firm entry timing, given the entry, is linked with the firm endogenous attitude to be a successful early-comer (or late-comer) in that particular market. Fixed the values for predetermined variables, firm entry behaviour should depend from some strictly endogenous parameters.

How can this be? Some of the previous argumentations provide the answer. Common sense tells us that it should be more plausible to observe an entry attempt into the US television-receiver market from an US radio manufacturer compared to an Italian canned food producer. But taken two US radio producers (and so a similar probability to enter), we should observe different entry timing decisions according to the different technological and marketing strengths of the two organizations. This line of reasoning leads to the second set of hypotheses:

Hypothesis 2a: With no inertia, predetermined firm characteristics affect the decision of "entry" versus "not entry" while specific endogenous, competencegrounded firm variables influence the entry timing decision

We turn now to the inertia assumption. From the Hypothesis $1 \mathrm{~b}$, the inertial decision procedure is similar to a repetitive decision of entry versus not entry that each period firms repeat. Entry timing is only a sub-product of this routinized process of decision. Under this assumption, firms do not take entry decision with a long run prospective, looking simultaneously at all the possible choices available. Firms decide whether entering with an early entry, or not. If they do not enter, they will review their decision in a late period. In doing so, inertial firm decisions are driven only by predetermined A-variables. If inertial firms collapse the twofold (entry and timing) decision in a

\footnotetext{
${ }^{9}$ This example takes inspiration from Klepper and Simons (2000).
} 
unique type of repeated decision, the B-variables that should affect entry timing do not operate.

Hypothesis 2b: With inertia, competence-grounded endogenous variables do not influence the entry timing decision. Only the predetermined firm characteristics affect both the decisions of entry and entry timing

\section{EMPIRICAL EVIDENCE}

From 1989 to 2000, among the 471 firms that entered in the market for encryption products, $6.15 \%$ were incumbents (entry by diversification), while $93.85 \%$ were startups (entry by new firm formation). The total number of products released in the market since 1989 is 1,269; large established firms account for $16.39 \%$ of these software packages. As stated before, this analysis focuses only on incumbent entry decisions, leaving for further research the study of start-up dynamics (see Giarratana, 2004). We agree in fact with some scholars (Bhide, 2000; Smith and Cooper, 1988) that entry by diversification is a different phenomenon compared to entry by new firm formation and it is better to analyze these issues separately.

From our database, we build a sample of 174 established firms which could be defined as potential entrants in ESI. We identify as potential entrants, firms that were granted at least a patent in 380 class from 1976 to 1999, or firms that signed at least a marketing alliance in ESI in the period 1990-1999, or firms that entered in ESI. Table 4 shows some preliminary statistics of potential entrants by sector. Differences in the average values for most variables are quite evident, confirming the heterogeneity of this sample.

\section{[Table 4 about here.]}

Graph 2 shows the distribution of incumbent entry timing; it is worth noting that the median value equals 8 , meaning that $50 \%$ of all the incumbents enter after a lag of 8 years from the product pioneer. This suggests that the reaction response of incumbents is characterized by some sort of wait-and-see attribute.

[Graph 2 about here.]

Following a standard methodology (Klepper and Simons, 2000), the empirical analysis will be conducted as follows: first we perform a Logit model to test the probability to enter and a Cox duration model to highlight the main drivers of the entry time dynamics. Then we try to collect the results in a unique estimation with a generalized Tobit model, testing whether data from ESI resemble more a rational than an inertial behavior.

Table 5 shows proxies used to capture the phenomenon.

[Table 5 about here.]

We divide the covariates in the two different groups; the first is composed by general sector and economic variables that, not directly linked with the ESI market, are neither directly controlled by firms nor modifiable in the short run (A-variable). The 
second is formed by B-variables that could be defined as assets tailored specifically to influence the entry in ESI and that firm could easily modify in the short run. In other words, potential entrants could be depicted by some characteristics that are quite generic and some that are strategic to enter in ESI. Below are further specifications on these variables:

- PAT tries to capture firm confidence and ability in catching-up strategies. The sounder the firm technological portfolio in cryptology, the more is firm confidence in overruling entry barriers, at least technological ones. In an entry timing regression model, Schoenecker and Cooper (1998) proxied firm R\&D intensity with R\&D expenditures. In this paper, patents represent a more accurate measure given that we can select with high precision the technological class that is strategic for the industry.

- ALL proxies firm evaluation of a new market's risks. The fact that a firm signs a number of commercial alliances in a sector before entry may signal the high level of market uncertainty perceived by this firm. Roughly speaking, taken two similar firms entered in a sector at the same time, their different number of pre-entry collaborative linkages should signal the different level of risk perceived by the firms ${ }^{10}$. It is a common strategy to use collaborative links as a mean to build a dedicated sales force and test market effective profitability. For the alliances we use the same sector precision as in the case of patents, selecting only the agreements classified with the SIC code 73726 (Encryption Software Sector).

- EXIT is a proxy of the level of competition inside the sector. It measures the commonly perceived risk of failure on new market.

- PROF measures the proportion between the size of the new market and the existing profit of the incumbent. This covariate aims to test the Aron and Lazear' (1990) assumption that firm tend to seek risky new markets when profits in existing businesses are decreasing.

- INT proxies the existing opportunity cost between the returns of the financial unrisky investments and the actual return of investments of the firm business. This variable captures the impact of liquidity constrains on firm's likelihood of pioneering new niches. On a work on firm financial constraints and firm behavior, Greenwald and Stiglitz (1990) suggest in fact "to relate variable like investment directly to firm financial conditions and to conditions of uncertainty ... in the economy at large" (p. 165).

- Sector dummies aim to capture the technological and downstream distance between sectors. The hypothesis is that due to technological and downstream proximities, it is easier to enter in ESI being a software firm rather than an electric component producer (see for example Teece et al., 1994). We introduce four dummy variables: software (SFW), hardware (HDW), diversified electronics (ELE) and telecommunications (TLC) ${ }^{11}$.

In order to control for firm size, we prefer to standardize by size firm-specific covariates rather than introducing size as a covariate. This is in order to avoid

\footnotetext{
10 Firms often use collaborative agreements in order to explore new markets and accumulate knowledge on them. The number of pre-entry alliances could signal the firm's need to obtain information on a particular sector. The more the information needed, the riskier is the firm perception of a market. At this regard see the Special Issue on "Strategic Network" of the Strategic Management Journal, 21 (2), 2000.
}

${ }^{11}$ We do not introduce the "OTHER" dummy to avoid singularity during the econometric tests. 
collinearity problems and to let firm specific variables play a more visible role. However, in Appendix B it is possible to find estimations using also these variables.

For those firms that did not enter until 2000 we make the assumption that they will never enter (data are right censored). This could also be true according to Mitchell's "dual clocks" theory (Mitchell, 1989). This theory affirms that potential entrants could not wait long after the entry of first large incumbents (such as IBM, H\&P and Computer Associates in ESI), since first mover advantages gained by large firms are difficult to overrun ${ }^{12}$.

The first estimation proposed is a standard Logit model, where the dependent variable assumes the value of 1 if the incumbent entered the market, 0 otherwise. Results are in Table 6. As predicted, only A-covariates explain the probability to enter. The probability to enter is only affected by the level of firm existing profits compared to the size of the new market, by sector proximities and by firm financial constrains. Hypothesis 1 is wholly confirmed.

\section{[Table 6 about here.]}

The second model is a Cox duration model, which specifies the hazard of entry of firm $i$ in year $t$ as $h_{t}=f(t) \exp (\beta x i)$, where the dependent variable is the probability of firm entry in year $t$ for firms that have not yet entered by year $t$.

\section{[Table 7 about here.]}

Maximum likelihood estimates of the Hazard model are in Table 7. B-covariates that represent firm tailored capabilities to enter in ESI do not affect the hazard of entry. On the other side, firm financial constrains, the software dummy and the low level of firm failure on the new market contribute to earlier entry. Hypothesis 1.b holds.

In order to reconsider these findings, we finally estimate a generalized Tobit equation (Amemiya, 1987), that merges the two previous models in a unique estimation. The generalized Tobit can be written as:

$$
\left\{\begin{array}{l}
Y=\alpha_{Y} X_{A}+\beta_{Y} X_{B}+\varepsilon \\
Z=\alpha_{Z} X_{A}+\beta_{Z} X_{B}+\gamma
\end{array}\right.
$$

where $Y=0,1$ is the dependent variable capturing the entry decision, $Z=1,2,3 \ldots$ is the dependent variable capturing the entry timing decision, $X_{A}$ and $X_{B}$ the two groups of covariates. The generalized Tobit in fact allows us to test separately the two types of decisions and the corresponding different magnitude and significance of coefficients in the two equations.

According to model results, under inertial assumption we expect that only the Avariables should be significant in explaining both the entry and the entry timing decision. In the case of full efficient behavior, the A-variables explain the decision of

\footnotetext{
12 Interviews conducted confirm this point. A product manager of a leading startup in ESI said: "Now there is no room for new vendors. A new competitor will find very hard times to gain market shares". Source: direct interview.
} 
entry, while the B-variables account for the decision of time of entry. So in econometric terms:

$\beta_{Y}=\beta_{Z}=0$ if the inertial assumption is confirmed,

while

$\beta_{Y}=\alpha_{Z}=0$ if the inertial hypothesis does not hold.

Given this clarification, we estimate a generalised Tobit model using the above covariates. Looking at the results (see Table 8), firm B-characteristic parameters (PAT and ALL) do not appear to be significant, while A-variables are significant in both the regressions. The inertial behavior seems be confirmed by ESI data (hypothesis 2.b). Data strengthen the assumption that incumbents adopt routinized, adapting mechanisms of decision that do not take in account all the available strategic instruments. Firm B-variables do not enter in the process of entry decision as a relevant strategic tool, while A-variables are strongly the drivers of firm behavior. Roughly speaking, firm entry timing decisions (in this case late or early) are blurred beyond a process of repetitive "rule of the thumb" interpretation of the competitive landscape. In so noticing, firm entry timing selection is not the direct outcome of a process of rational decision on timing, given the entry decision, but it is a "subproduct" of an entry-vs-no entry algorithm that each time firms activate until there is a window of opportunity. In order to confirm this view, we calculated the Pearson correlation coefficient among residuals of the two estimations, $\varepsilon$ and $\gamma$. The correlation coefficient equals 0.377 with a significance level of 0.002 .

\section{[Table 8 about here.]}

Moreover, Table 9 shows some descriptive statistics for the most populated entry time cohorts. It is clear-cut that inside these cohorts there is high heterogeneity among firms. Why firms that are so different take the same entry timing decision? Our answer is that, fixed the Avariables, entry timing decisions of dissimilar firms could coincide, if B-variables are negligible elements in firm decision processes.

\section{[Table 9 about here.]}

We want to highlight that we introduce as firm-specific covariates two variables that are tailored to model the entry in ESI, because directly correlated with the ability of incumbents to enter in this market. A previous work (Giarratana, 2004) showed that these are the main factors beyond start-ups success in ESI. This point is one of the major novelties of this paper: firm specific competences that should influence entry timing are unimportant ${ }^{13}$. However, to allow a more general interpretation of the phenomenon, we try to perform again the generalised Tobit using other (and more generic) firm specific variables like firm sales, firm age and firm level of diversification ${ }^{14}$. The results ${ }^{15}$ do not change since also these variables appear to be not significant. The T-statistics for Log(sales) in the Probit equation is 1.150 ( $p$-value

\footnotetext{
${ }^{13}$ This holds also when PAT and ALL are not standardized for firm size.

14 Firm diversification is proxied using the Herfindahl index calculated on firm trademarks over the period. Data were downloaded from the USPTO Patent Office.

${ }^{15}$ See Appendix B.
} 
0.25 ) and 0.586 ( $p$-value 0.557$)$ for the regression equation. For the age variable the T-statistics is $-1.745(0.08)$ and $1.807(0.07)$ and for firm diversification $0.458(0.654)$ and 0.785 (0.442).

If we think that firms are to some extent inertial, the most obvious effect is the similarities of entry timing patterns among different firms. Geroski and Mazzuccato (2001) have coined the term of "speculative bubble" to assess a highly optimistic forecasts of future profitability of new markets that led to high rate of entry in similar periods. ESI data show that firms take entry timing decisions not considering firm specific assets that could favour the entry process. This clearly satisfies the evidence that entry is not a smooth, homogeneous phenomenon, but it occurs in waves (Geroski, 1995). Assuming firm heterogeneity, if entry decisions were influenced by firm specific B-variables, we would observe a homogenous, poorly concentrated distribution of firms over different entry time options. If every firm has its own characteristics, so it should have its own optimal entry timing decision. While if sector and external variables are the drivers of the phenomenon, entry timing decisions will be with high probability identical among potential entrants, leading to points of firm entry agglomeration in time ${ }^{16}$.

Data in ESI confirm this finding. Graph 3 shows the growth rates of gross entry in ESI. It is evident the wave morphology of the entry process in this industry.

[Graph 3 about here.]

We now discuss specifically the meaning of each estimate:

- PROF is significant in the entry decision, but not in the entry timing decision. This means that, given the entry, the size of firm actual business, compared to the size of new markets, does not affect the decision of time of entry. The sign is in line with prediction: the less is the level of the profits in the existing business, the higher is the firm probability to enter in new business.

- EXIT is significant when decision of entry timing is considered. The positive sign of the estimate stresses that when the rate of firm exit is high, firms tend to postpone entry. The more the risk of failure, the more a wait-and-see strategy is played.

- INT is significant in both the regressions. In the first regression, its sign is positive; this finding means that the less is firm $\mathrm{ROI}$, compared to the un-risky investment, the more the firm will try diversification strategies. In the entry timing regression, the sign is negative which means that the higher is this ratio, the earlier will firm enter. This is also in line with the predictions.

- SECT Sector dummies are very important in the entry decision process. All dummies are significant. Data confirm an important regularity: among all firms it was easier to enter in ESI for software or hardware producers. Sector proximities make a difference; this finding is quite important because to find this hypothesis tested in literature is quite uncommon. In the entry timing decision process, only the software dummy variable remains significant, indicating that sector differences count less in the process of entry timing decision.

Trying to draw some general insights from these results, the entry decision is influenced mainly by the proximity between the new and the firm core business and by the level of expected average profitability of the new market, compared to the existing level of firm profits. Conversely, entry timing decision is determined by the

\footnotetext{
16 The fact that some imitative behaviour exists among potential entrants could only corroborate the evidence that control variables poorly contribute in the entry process.
} 
level of competition in the new market and by the actual level of market financial liquidity.

\section{POLICY IMPLICATIONS}

Several policy implications arise from this work. First, incumbents, especially large firms with consolidated catching-up strategies, tend to enter late into new product fields. Opening and testing new market niches is not a job that every firm wants to perform. But if latecomers are also the owners of the technology required in new markets, and they strongly protect their technology against use by potential entrants, this could lower the diffusion of innovations and the pace of new market generation. Particular attention should be given to the breadth and the length of patent protection, in a way that it should not harm both the incentives to innovate and the innovative application of existing knowledge by other firms (Merges and Nelson, 1990). The case of ESI is a good example: patents that act as a technological base for further enhancements in cryptology are twenty years old, without any strong protection from other firm applications. This point should be linked to the recent trend of some high-tech firms to place barriers on the mobility of high-skilled personnel not allowing for example their researchers to form spin-offs. Literature indicates that the exploration and testing of new markets is one of the most important roles performed by start-ups, a role that large established firms do not always want to play. This startup function could be slowed down through an excessive protection of proprietary knowledge by incumbents. In ESI the most successful founders had work experience in large ICT firms, with high technological and organization capabilities (Giarratana, 2004).

The second point is that if firms are inertial, they will take their entry decisions looking mainly to pre-determined, quasi-fixed variables. According to these predictions, firm entry decisions could easily collide. This is not against the evidence that entry occurs in waves. Homogenous entry decisions could convey congestion in markets with an excess of competition in some phases of industry history, causing a replication of investments and research projects, and increasing the rate of firm failure. Our suggestion is that policy interventions and venture capital strategies should be redirected to sustain entry not only when new markets are "fashionable", but whenever firm entry is grounded on sound and innovative competences.

\section{STRATEGIC IMPLICATIO NS AND CONCLUSIONS}

This paper was centered on the issue of incumbent entry timing in ESI. We have separated the different strategic outcomes depending on the level of inertia that could hit potential entrants. Then, we have tested our assumptions on ESI data, finding evidence to support, as we defined it, a "myopic", inertial behavior of incumbent firms. More precisely, we have found that firm specific competences do not play a significant role in incumbent entry timing strategies. We have suggested that this could be explained by an assessment process that fails to accommodate the full logic of decision.

But these findings open the table for further discussions. At this regard, two could be the models underneath this evidence. The hypothesis sustained along this paper claims that incumbents suffer from inertia in entry decision processes, overlooking 
some assets that could improve their competitive position in new markets. This implies that incumbent entry performance is sub-optimal and it could be increased if firms adopt a more rational use of their resources.

But another explanation, not yet discussed, could be that incumbents do not compete in new markets using timing of entry as a strategic variable, considering irrelevant firm assets that influence entry timing. Which of these assumptions is the real mechanism beyond incumbent entry patterns?

Further works that includes an extensive survey among managers of incumbent firms could give new insights over this problem. Nonetheless, we try to link these two hypotheses with one of the question posed at the beginning of this work: whether large incumbents to some extent "forget" their technological inventories allowing technological imitators to dominate new market niches. Answering this question claims a carefully analysis. From one side, and also our analysis is consistent with that, for incumbents the timing of entry in a technological and in a product race are different. Incumbents enter early into new technological fields, maybe because they use competences embedded in existing products (Gambardella and Torrisi, 1998), probably without any considerations about the possibility to exploit these capabilities in future markets.

But building a large, diversified technological base could be a necessary condition to maintain a chance to enter promptly into new markets when an inertial entry decision will be taken. These incumbents simply set a strategy of "not being too far" at least technologically (Schnaars, 1994). Along this view, large incumbents do not "forget" part of their technological portfolio. They often invest in searching along the new technological trajectories, even if they wait to enter into new product markets. At this regard, the persistence of large firm patenting in cryptology is quite striking. Building a large diversified technological portfolio could reduce the cost of playing a wait-andsee strategy, increasing simultaneously the probability to play this strategy. Sound investments in firm ability to be late-comers, namely investing in a wide firm knowledge base, could be a necessary condition (and maybe the only) to sterilize the harmful effects of inertia. Otherwise, and predictions could be straight on this point, incumbents that do not consider the right entry timing will experience a higher probability of failure. To be clearer, maybe only for fat-competence organizations entry timing could poorly influence firm performance in new sectors and it can be considered an irrelevant strategic tool. But adapting rules of decision that could give high payoffs to these fat-competence firms could not guaranteed the same results if transferred to other organizations. Our data show that not all the incumbents are fatcompetence organizations and for these companies, missing the starting gun could be a key issue.

ESI gives a quintessential example of wrong entry timing decision that causes firm failure. SystemSoft was a medium size company specialized in operating system design that has tried to exploit ESI rising demand since 1993. It focused its production on utility software programs and developed system-level software that let a PC's hardware communicate with its operating system. Following this strategy, it signed several technological and marketing agreements with large ICT firms and in 1996 it bought Radish Communications System, with the aim of integrating Radish's competencies in data transmission technology. But Systemsoft never coped with its direct competitors like Network Associates and Symantec that entered in the sector some years before. After having realized a loss in 1997, the firm tried to react with cost saving strategies but in 1999 the company filed for bankruptcy protection. In 
1999 Systemsoft sold off its assets to Rocket Software (BusinessWire, 1999). Similar case studies could also be found in other sectors ${ }^{17}$.

Trying to conclude, one of the major questions that this work has raised is the following: are we dealing with problems of entry decision inertia or incumbent competitive advantages are not influenced by entry timing in new markets?

The issue could find an answer assuming that incumbents could be affected by inertia, but that the strategic relevance of entry timing decreases with firm age, experience, size and knowledge base breadth. Therefore, wrong entry timing decisions could be less damaging for fat-competence organizations, since when firms become large, entry timing loses its strategic value ${ }^{18}$. Some empirical evidence showing a positive relationship between firm performance and strategic decision speed could give more corroboration to the latter point (Baum and Wally, 2003).

Unfortunately, one evident limitation of this work is that we could not measure the post-entry performance of all incumbents in ESI. To have a rough proxy of incumbent performance in ESI, we have checked in the US Trademarks database if the firms entered in ESI still own some trademarks referred to encryption software products at December 2002, after two years from our sample period ${ }^{19}$. At $200239.2 \%$ of incumbents that entered in ESI do not own any live trademarks in encryption software, quite sound evidence that these firms exited the market. The two incumbents that own the most live trademarks in encryption software are not surprising the two "fattest" competence firms in our sample: IBM (28) and H\&P (10). Moreover, direct interviews conducted with some start-up managers confirm that leading early-comer start-ups have gained sound first mover advantages, especially in terms of downstream assets and product reputation. In these interviews, it surprisingly emerged that often start-ups does not perceive large incumbents as direct competitors, even if they started to sell their own products in ESI. Start-ups keep referring to large firms as best customers or best partners. It seems that incumbents are not playing a leading role in this industry and some problems in the entry timing process should exist.

We are aware that entry process is analyzed in a particular niche of software industry characterized by low entry and exit barriers and high turbulence. These characteristics affected the modality of entry and the decision processes activated by potential entrants. Further works should investigate these issues in other industries.

Finally, let us conclude with a challenging point, though speculative. This paper has disclosed how inertial behavior reduces the strategic value of firm-specific, dynamic capabilities. Even with perfect information on all the variables, firm top managers should be aware that strategic mistakes could also reside in a biased cognitive balance of the strategic instruments available. At this regard, we think that the

\footnotetext{
${ }^{17}$ See for example WMX technologies case (Forbes, 1993).

18 Being a large, long-living diversified firm often means that past entry timing decisions were successful, especially in the early firm history. Given this, any scholar could suggest that long-living, fat-competence firms are those that have used rational entry decision processes in the first stages of their growth. It could be of great interest to test this hypothesis in further works.

${ }^{19}$ For incumbents entered in ESI, we checked for all the trademarks that 1) are live at December 2002; 2 ) in the Good and Service description include the words "software" and "encryption or encrypting or security or secure". It is worth noticing that a trademark could be dismissed by firms (abandon) or by the USPTO authority (cancellation) after 6 years from the registration if the trademark is not used anymore. This means that the effective date of exit is observed with delay.
} 
difference in the extent of performance could lie not only in the quality of the observation, but also in the validity of the inference.

\section{REFERENCES}

Amemiya, T. 1987. Advanced Econometrics, Harvard University Press.

Aron, D., Lazear, E. 1990. The Introduction of New Products, American Economic Association: Papers and Proceedings , 80(2): 421-426.

Arora, A., Fosfuri, A. and Gambardella, A. 2002. Markets for Technology , MIT Press.

Audretsch D.B. 1991. New Firm Survival and Technological Regime, The Review of Economics and Statistics, 73(3): 441-450

Barr, P. 1998. Adapting to Unfamiliar Enviromental Events: a Look at the Evolution of Interpretation and its Role in Strategic Change, Organization Studies, 9(6): 644668.

Baum J.R., Wally S. 2003. Strategic Decision Speed and Firm Performance, Strategic Management Journal, 24: 1107-1129

Bessen, J., Hunt, R. 2003. An Empirical Look at Software Patents, Mimeo.

Bhide, A. 2000. The Origin and Evolution of New Businesses , Oxford University Press.

Bresnahan, T. 1985. Post-Entry Competition in the Plain Paper Copier Market, American Economic Association: Papers and $P$ roceedings, 75(2):15-19.

Brock, W., Hommes, C. 1997. A Rational Route to Randomness, Econometrica, 65(5): 1059-1095.

BusinessWire. 1999. Systemsoft to file for Protection under Chapter 11 of the US Bankruptcy Code', March: 28-31.

Carroll G.R., Bigelow L.S., Seidel M.D.L., Tsai L.B. 1996. The fates of de novo and de alio producers in the American automobile industry 1885-1981. Strategic Management Journal, Summer Special Issue 17: 117-137.

Chesbrough, H. 2000. Designing Corporate Ventures in the Shadow of Private Venture Capital, California Management Review , 42(3): 31-49.

Cho, D., Kim, D. and Rhee, D. 1998). Latecomer Strategies: Evidence from Semiconductor Industry in Japan, Organization Studies, 9(4): 489-505.

Christensen, C. 1997. The Innovator's Dilemma , Harvard Business School Press, Boston.

Conlisk, J. 1996. Why Bounded Rationality?, Journal of Economic Literature , 34(2): 669-700.

Dougherthy, D., Hardy, C. 1996. Sustained Product Innovation in Large, Mature Organizations: Overcoming Innovation to Organization Problems, Academy of Management Journal, 39(5): 1120-1153.

Dougherthy, D., Heller, T. 1994. The Illegitimacy of Successful Product Innovation in Established Firms, Organization Studies, 5(2): 200-218.

Dowell, G., Swaminathan, A. 2000. Racing and Back-pedalling into the Future: New Product Introduction and Organizational Mortality in the US Bicycle Industry', Organization Studies, 21(2): 405-431.

Forbes. 1993. Dean Buntrock's Green Machine, 152(3): 96-101.

Gambardella, A., Torrisi, S. 1998. Does Technological Convergence Imply Convergence in Markets? Evidence from the Information Technology Industry, Research Policy, 27(6): 445-463. 
Geroski, P. 1995. What do We Know about Entry?, International Journal of Industrial Organization, 13(4): 421-440.

Geroski, P., Mazzucato, M. 2001. Modelling the Dynamics of Industry Populations, International Journal of Industrial Organization , 19(7): 1003-1023.

Giarratana, M. S. 2004. The Birth of a New Industry: Entry by Start-ups and the Drivers of Firm Growth. The Case of Encryption Software, Research Policy, Forthcoming

Greenwald, B. Stiglitz, J. 1990. Asymmetric Information and the New Theory of the Firm: Financial Constraints and Risk Behavior, American Economic Association: Papers and Proceedings , 80(2): 160-165.

Grever, H., Taylor, A. 2000. Innovations as Catalysts for Organizational Change: Shifts in Organizational Cognition and Search, Administrative Science Quarterly , 45(3): 45-80.

Hannan, M., Freeman, J. 1984. Structural Inertia and Organization Change, American Sociological Review, 49(2): 149-164.

Henderson, R. 1993. Underinvestment and Incompetence as Responses to Radical Innovation: Evidence from Photolithographic Alignment Equipment Industry, Rand Journal of Economics , 24(2):248-270.

Henderson, R., Clark, K. 1990. Architectural Innovation: the Reconfiguration of Existing Product Technologies and the Failure of Established Firms, Administrative Science Quarterly, 35(1): 9-30.

Jaffe, A., Trajteberg, M. and Fogarty, M. 2000. Knowledge Spillover and Patent Citations: Evidence from a Survey of Inventors, American Economic Review , 90(2): 215-218.

Jelinek, M. 1977. Technology, Organizations and Contingency, Academy of Management Review, 2(1): 17-26.

Katz, M. and Shapiro, C. 1987. R\&D Rivalry with Licensing or Imitation', American Economic Review, 77(3). 402-420.

Klepper, S. 2001. Employee Start-ups in High-tech Industry, Industrial and Corporate Change, 10(3): 639-674.

Klepper, S., Simons, K. 2000. Dominants by Birthright: Entry of Prior Radio Producers and Competitive Ramifications in the US Television Receiver Industry, Strategic Management Journal, 21: 997-1016.

Levin R., Klevorick A, Nelson R.R., and Winter S. 1987. Appropriating the Returns from Industrial Research and Development. Brookings Papers on Economic Activity 3: 783-820.

Levinthal, D., March, J. 1993. The Myopia of Learning, Strategic Management Journal , 14: 95-112.

Lieberman M.B., Montgomery D.B. 1988. 1st Mover Advantages. Strategic Management Journal, 9: 41-58

March, J. 1988. Decisions and Organizatio ns, Basic Blackwell.

Merges, R., Nelson, R. 1990. On the Complex Economics of Patent Scope, Columbia Law Review, 90(2): 839-870.

Miller K.D. 2002. Knowledge Inventories and Managerial Myopia, Strategic Management Journal, 23: 689-706

Mitchell, W. 1989. Whether and When? Probability and Timing of Incuments Entry into Emerging Industrial Subfields', Administrative Science Quarterly , 34(2): 208230. 
Mitchell, W. 1991. Dual Clocks: Entry Order Influences on Incumbents' and Newcomer Market Share and Survival when Specialized Assets retain their Value, Strategic Management Journal, 12(2): 85-100.

Montgomery, C. 1994. Corporate Diversification, Journal of Economic Perspectives , 8(3): 163-178.

Mowery, D., Oxley, J. and Silvermann, B. 1998. Technological Overlap and Inter-firm Cooperation: Implications for the Resource-based View of the Firm, Research Policy, 27(3): 507-523.

Mueller, D. 1997. First-mover Advantages and Path Dependence, International Journal of Industrial Organization, 15(2): 827-850.

Pavitt, K., Patel, P. 1997. The Technological Competence of World's Largest Firms: Complex and Path Dependent, but not Much Variety, Research Policy, 26(2): 141-156.

Rubin, P. 1973. The Expansion of Firms, Journal of Economic Perspectives , 81(3): 936-949.

Scherer, F. 1980. Industrial Market Structure and Economic Performance, Rand McNally, Chigago.

Schnaars, S. 1994. Managing Imitation Strategies, Free Press, NY.

Schoenecker, T., Cooper, A. 1998. The Role of Firm Resource and Organizational Attributes in Determining Entry Timing: a Cross-Industry Study, Strategic Management Journal, 19(2): 1127-1143.

Shane, S. 2001. Technological Regimes and New Firm Formation, Management Science, 47(9): 1173-1190.

Silverman, B. 1999. Technological Resources and the Direction of Corporate Diversification: towards an Integration of Resource Based View and Transaction Cost Economy, Management Science, 45(8): 1109-1124.

Smith, C., Cooper, A. 1988. Established Companies Diversifying into Young Industries: a Comparison of Firms with Different Levels of Performance, Strategic Management Journal, 9(2): 111-121.

Smith, R. 1999. Internet Cryptography, Addison-Wesley, Reading USA.

Teece, D., Rumelt, R., Dosi, G. and Winter, S. 1994. Understanding Corporate Coherence: Theory and Evidence, Journal of Eco nomic Behavior and Organization, 23(2): 1-30.

Teece, D.J, Pisano, G. Shuen , S. 1997. Dynamic Capabilities and Strategic Management, Strategic Management Journal, 18: 509-33.

Tushman, M., Anderson, P. 1986. Technological Discontinuities and Organizational Enviroments, Administrative Science Quarterly, 31(2): 439-465.

Vanderwerf P., Mahon J.F. 1997. Meta-Analysis of the Impact of Research Methods on Findings of First-Mover Advantages. Management Science. 43: 1510-1519

Winter S. 2003. Understanding dynamic capabilities, Strategic Management Journal, 24 (10): 991-995.

Winter, S. 1987. Knowledge and Competence as Strategic Assets, in D. Teece, ed., The Competitive Challenge: Strategies for Industrial Innovation and Renewal, Harper, NY, pp. 159-184. 


\section{APPENDIX A: DATA SOURCE DESCRIPTIO}

Patent data are downloaded from the US Patent Office web site,(www.uspto.gov). We considered all the patents in the US class 380 (Cryptography) that include "equipment and processes wh ich a) conceal or obscure intelligible information by transforming such information so as to make the information intelligible to a casual or un -authorized recipient, or b) extract intelligible information from such a concealed representation, including br eaking of unknown codes and messages" (see Us Patent Office classification manual). For each patent we extracted all the information reported in the on-line front page of the patent (issue date, assignee, citations, inventors).

Information about alliances was drawn from Infotrac's Insite Promt database (www.insitepro.com), that reports four categories of firm events (strategic alliances, joint ventures, M\&As) from a large set of trade journals, magazines and other specialized press. For the period 1993-1999 we downloaded all the events included in the SIC Code 73726 (Encryption Software Sector).

Products introduction data were taken from Infotrac's General Business File ASAP database, downloading all the press articles that report a "Product announcement", "New software release" and "Software Evaluation" in the security software sector. Firm entry was assigned when the first firm product was released in the market.

Firm's financial data were taken from Hoover's (www.hoovers.com), an on-line database, which collects data for the Security Software \& Services industry.

Data on the structure of firm groups (including subsidiaries) were taken from Business and Company Resource Center database, Gale Group's Infotrac.

\section{APPENDIX B: ALTERNAT IVE ESTIMATION}

\begin{tabular}{|l|c|c|c|}
\hline \multicolumn{4}{|c|}{ Log of Likelihood Function $=-95.0303 \quad \mathrm{~N}=174$} \\
\hline Variable & Estimate & S.E. & T-Test \\
\hline \multicolumn{4}{|c|}{ Probit Estimation } \\
\hline Costant & -4.576 & 1.032 & -4.432 \\
\hline AGE & -2.181 & 1.250 & -1.745 \\
\hline SIZE & 0.056 & 0.049 & 1.150 \\
\hline PROF & 0.068 & 0.063 & 1.069 \\
\hline INT & 1.330 & 0.129 & 10.2 \\
\hline EXIT & -47.160 & 4.830 & -9.74 \\
\hline HDW & 1.219 & 0.378 & 3.222 \\
\hline SFW & 1.134 & 0.331 & 3.425 \\
\hline ELE & 0.248 & 0.312 & 0.792 \\
\hline \multicolumn{5}{|c|}{ Regression Estimation } \\
\hline Costant & -6.758 & 2.537 & -2.664 \\
\hline AGE & 4.349 & 2.406 & 1.807 \\
\hline SALES & 0.118 & 0.201 & 0.586 \\
\hline PROF & 0.046 & 0.014 & 3.321 \\
\hline EXIT & -50.620 & 0.928 & -54.542 \\
\hline \multicolumn{4}{|l|}{}
\end{tabular}




\begin{tabular}{|l|r|r|r|}
\hline INT & -0.491 & 0.544 & -0.902 \\
\hline HDW & 2.328 & 0.809 & 2.878 \\
\hline SFW & 2.417 & 1.348 & 1.793 \\
\hline ELE & 0.305 & 1.816 & 0.168 \\
\hline
\end{tabular}

Table 1: Most cited firms in 380 USPTO Class, sample patents 1976-1992

\begin{tabular}{|l|r|r|r|}
\hline Firm & Citations (C) & Patents (P) & $\mathbf{C} / \mathbf{P}$ \\
\hline IBM & 528 & 46 & 11.47 \\
Motorola & 226 & 24 & 9.41 \\
Scientific Atlanta & 202 & 18 & 11.22 \\
Pitney Bowes & 165 & 16 & 10.31 \\
Qualcomm & 97 & 3 & 32.33 \\
AT\&T & 97 & 8 & 12.12 \\
Pioneer & 95 & 9 & 10.55 \\
Philips & 95 & 7 & 13.57 \\
Aisin Seiki & 83 & 6 & 13.83 \\
Stanford University & 80 & 2 & 40 \\
M.I.T. & 75 & 2 & 37.5 \\
NEC & 72 & 6 & 12 \\
General Instr. & 68 & 8 & 8.5 \\
NCR & 63 & 5 & 12.6 \\
Hitachi & 62 & 4 & 15.5 \\
VISA & 53 & 2 & 26.5 \\
\hline Total & 2061 & 166 & 17.34 \\
Other & 2520 & 224 & 11.81 \\
\hline
\end{tabular}

Source: USPTO

Table 2: Top firms for patents granted 1993--1999 in 380 USPTO Class

\begin{tabular}{|l|l|l|r|}
\hline Top firms & Country & Sector & Patents granted \\
\hline IBM & USA & Computer & 195 \\
Motorota & USA & Telecom & 175 \\
Sony & Japan & Electronics & 71 \\
Scientific Atlanta & USA & Telecom & 64 \\
Pitney Bowes & USA & Computer & 61 \\
Matsushita & Japan & Electronics & 54 \\
ATT & USA & Telecom & 52 \\
Fujitsu & Japan & Computer & 50 \\
Compaq & USA & Computer & 44 \\
Toshiba & Japan & Computer & 43 \\
\hline Total & & & 809 \\
Other & & & 2265 \\
\hline
\end{tabular}

Source: USPTO 
Table 3: Top firms cited by "ESI 1998 market leader" patents at 1999

\begin{tabular}{|l|r|}
\hline Firm cited & Numbers of Citations \\
\hline IBM & 43 \\
Motorota & 27 \\
Compaq-HP & 23 \\
Science Applications & 19 \\
AT\&T & 18 \\
Sun & 14 \\
Matsushita & 13 \\
Secure Computing & 13 \\
NSA Labs & 11 \\
Interdigital & 9 \\
Total & 190 \\
Other & 256 \\
\hline
\end{tabular}

Source: USPTO

Table 4: Sample composition. Potential entrants in ESI by sector, 1989-2000 (average values)

\begin{tabular}{|l|r|r|r|r|r|}
\hline Sector & Firms & $\begin{array}{r}\text { Commercial } \\
\text { Alliances }\end{array}$ & $\begin{array}{r}\text { Patents } \\
\text { after 1992 }\end{array}$ & $\begin{array}{r}\text { Patents } \\
\text { before 1992 }\end{array}$ & $\begin{array}{r}\text { Sales } \\
\text { ('000\$) }\end{array}$ \\
\hline Electronics & 46 & 1.61 & 17.25 & 1.42 & 16,612 \\
\hline Hardware & 29 & 2.30 & 29.05 & 4.70 & 9,137 \\
\hline Software & 32 & 1.78 & 9.54 & 0.09 & 2,084 \\
\hline Telecommunications & 29 & 1.81 & 25.08 & 2.21 & 13,274 \\
\hline Other & 38 & 1.81 & 8.29 & 0.19 & 71177 \\
\hline Total & 174 & & & & \\
\hline
\end{tabular}

Source: Infotrac, USPTO, Hoover's

Table 5: Covariates description

\begin{tabular}{|l|l|}
\hline \multicolumn{2}{|c|}{$A$ variables } \\
\hline PROF & $\begin{array}{l}\text { Ratio between firm profit in existing businesses and average } \\
\text { profit in ESI }\end{array}$ \\
INT & Ratio between annual average interest rates of US Treasury \\
& Bonds and annual firm Return of Investment. \\
EXIT & Ratio between firm exit and entry rate in ESI \\
HDW & Sector dummy for hardware incumbents \\
SFW & Sector dummy for software incumbents \\
TLC & Sector dummy for telecommunication incumbents \\
ELE & Sector dummy for diversified electronic incumbents \\
\hline \multicolumn{2}{|c|}{$B$ variables } \\
\hline PAT & $\begin{array}{l}\text { Pre-entry number of firm patents in 380 USPTO class 1976- } \\
\text { 1999, weighted by citations, standardised by firm size (logsales) }\end{array}$ \\
ALL & Pre-entry number of firm commercial alliances in the sector, \\
& standardised by firm size (logsales)
\end{tabular}


Table 6: Results of Logit estimation - Entry probability

\begin{tabular}{|l|r|r|r|}
\hline \multicolumn{4}{|l|}{ Log Likelihood $=-51.4764 \quad N=174$} \\
\hline Variable & Estimate & S.E. & T-Test \\
\hline Constant & -5.766 & 1.417 & -4.066 \\
PAT & 0.011 & 0.25 & 0.046 \\
ALL & 0.455 & 0.258 & 1.759 \\
PROF & -0.495 & 0.147 & -3.364 \\
EXIT & 0.103 & 0.124 & 0.831 \\
INT & 0.234 & 0.092 & 2.543 \\
HDW & 4.139 & 1.434 & 2.885 \\
SFW & 4.005 & 1.43 & 2.799 \\
TLC & 2.627 & 1.377 & 1.907 \\
ELE & 2.095 & 1.441 & 1.453 \\
\hline
\end{tabular}

Table 7: Results of Cox estimation - Hazard of entry

\begin{tabular}{|c|c|c|c|}
\hline Log Like & $N=1$ & & \\
\hline Variable & Estimate & S.E. & T-Test \\
\hline PAT & -0.005 & 0.003 & -1.379 \\
\hline ALL & 0.082 & 0.261 & 0.313 \\
\hline PROF & 0.006 & 0.010 & 0.560 \\
\hline EXIT & -7.770 & 1.496 & -5.192 \\
\hline INT & 0.986 & 0.325 & 3.034 \\
\hline HDW & 1.460 & 1.046 & 1.396 \\
\hline SFW & 2.447 & 1.013 & 2.416 \\
\hline TLC & 1.637 & 0.984 & 1.662 \\
\hline ELE & 1.011 & 0.993 & 1.018 \\
\hline
\end{tabular}


Table 8: Results of generalised Tobit estimation

\begin{tabular}{|c|c|c|c|}
\hline \multicolumn{4}{|c|}{ Log of Likelihood Function $=-97.7161$} \\
\hline Variable & Estimate & S.E. & T-Test \\
\hline \multicolumn{4}{|c|}{ Probit Estimation } \\
\hline Constant & -2.592 & 0.271 & -9.565 \\
\hline PAT & 0.000 & 0.001 & -0.588 \\
\hline ALL & 0.646 & 0.358 & 1.806 \\
\hline PROF & -2.978 & 1.090 & -2.731 \\
\hline EXIT & 0.154 & 0.100 & 1.537 \\
\hline INT & 0.346 & 0.109 & 3.161 \\
\hline HDW & 2.358 & 0.353 & 6.671 \\
\hline SFW & 1.470 & 0.288 & 5.102 \\
\hline TLC & 1.054 & 0.271 & 3.893 \\
\hline ELE & 1.075 & 0.251 & 4.281 \\
\hline \multicolumn{4}{|c|}{ Regression Estimation } \\
\hline Constant & 11.022 & 1.573 & 7.009 \\
\hline PAT & 0.000 & 0.000 & -1.592 \\
\hline ALL & 0.274 & 0.502 & 0.545 \\
\hline PROF & -0.018 & 0.086 & -0.205 \\
\hline EXIT & 3.460 & 1.526 & 2.267 \\
\hline INT & -0.165 & 0.075 & -2.202 \\
\hline HDW & 2.712 & 1.815 & 1.495 \\
\hline SFW & -3.909 & 1.798 & -2.174 \\
\hline TLC & 3.240 & 2.721 & 1.191 \\
\hline ELE & 3.925 & 2.479 & 1.583 \\
\hline
\end{tabular}

Table 9: Descriptive statistics of most populated entry cohorts

\begin{tabular}{|lr|r|r|r|r|}
\cline { 2 - 6 } \multicolumn{1}{c|}{} & \multicolumn{5}{c|}{ Alliances } \\
\hline Contry Time & $\mathbf{1 2}$ & $\mathbf{1 0}$ & $\mathbf{9}$ & $\mathbf{8}$ & $\mathbf{7}$ \\
\hline Average & 3.5 & 2.8 & 22.6 & 4.42 & 3.33 \\
Stand. Dev. & 2.12 & 2.38 & 7.76 & 3.69 & 3.21 \\
Max & 5 & 7 & 29 & 10 & 7 \\
Min & 2 & 1 & 14 & 1 & 1 \\
\hline Average & \multicolumn{5}{|c|}{ Patents } \\
Stand. Dev. & 42 & 11.8 & 32 & 34.1 & 20.6 \\
Max & 16.97 & 7.46 & 22.11 & 72.8 & 35.7 \\
Min & 54 & 19 & 57 & 198 & 62 \\
\hline & 30 & 2 & 15 & 0 & 0 \\
\hline Average & \multicolumn{7}{|c|}{ Sales ('000\$) } \\
Stand. Dev. & 11,737 & 5,800 & 1,896 & 14,284 & 21,159 \\
Max & 16,561 & 5,011 & 841 & 27,625 & 36,555 \\
Min & 23,448 & 12,983 & 2,631 & 76,347 & 63,370 \\
\hline
\end{tabular}


Source: Infotrac, USPTO, Hoover's 
Figure 1: Entry, exit and firms on the market in ESI, 1989-2000

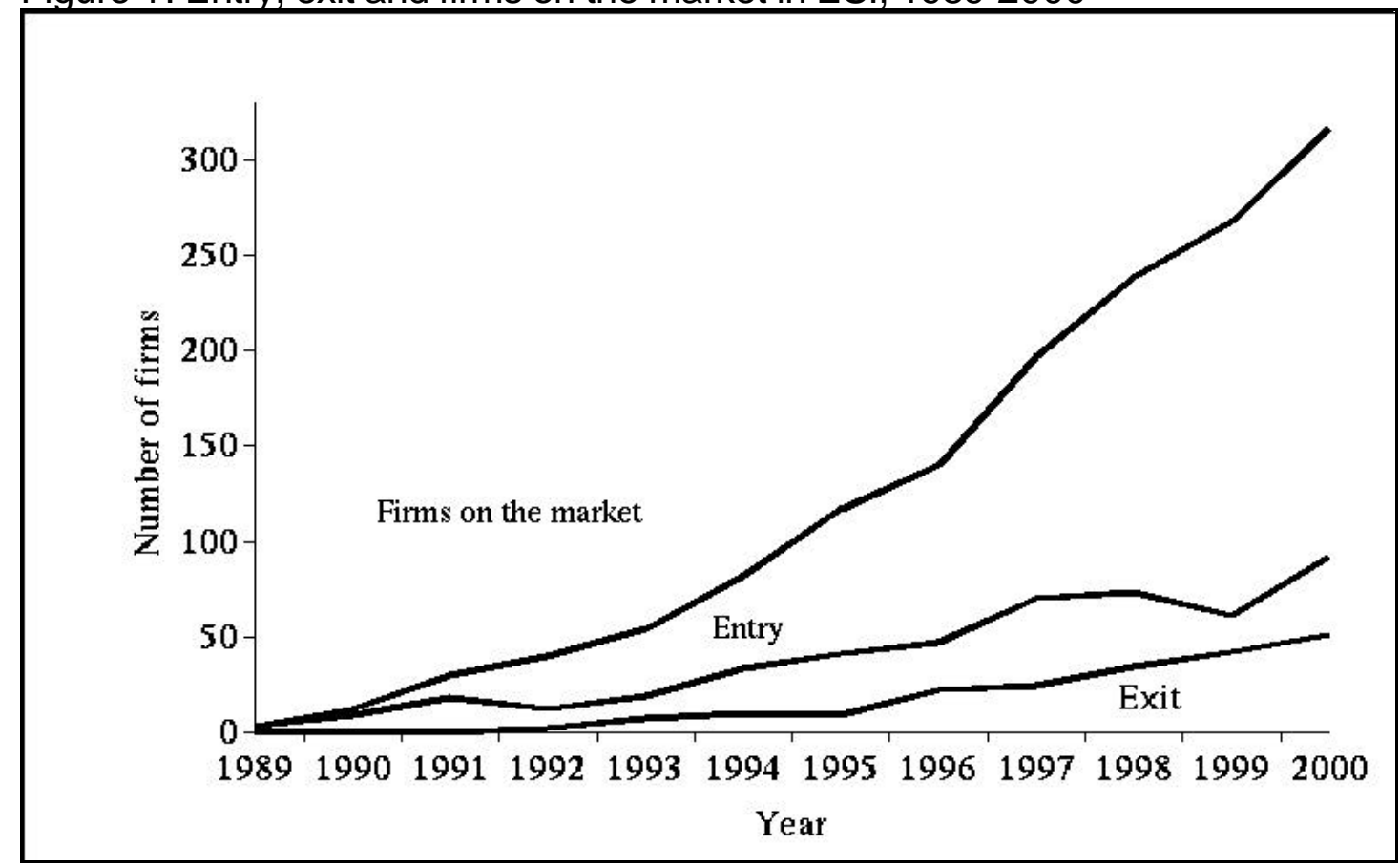

Source: Infotrac Business Source ASAP

Graph 2: Time distribution of incumbent entry in ESI. 1989 (0) - 2000 (12)

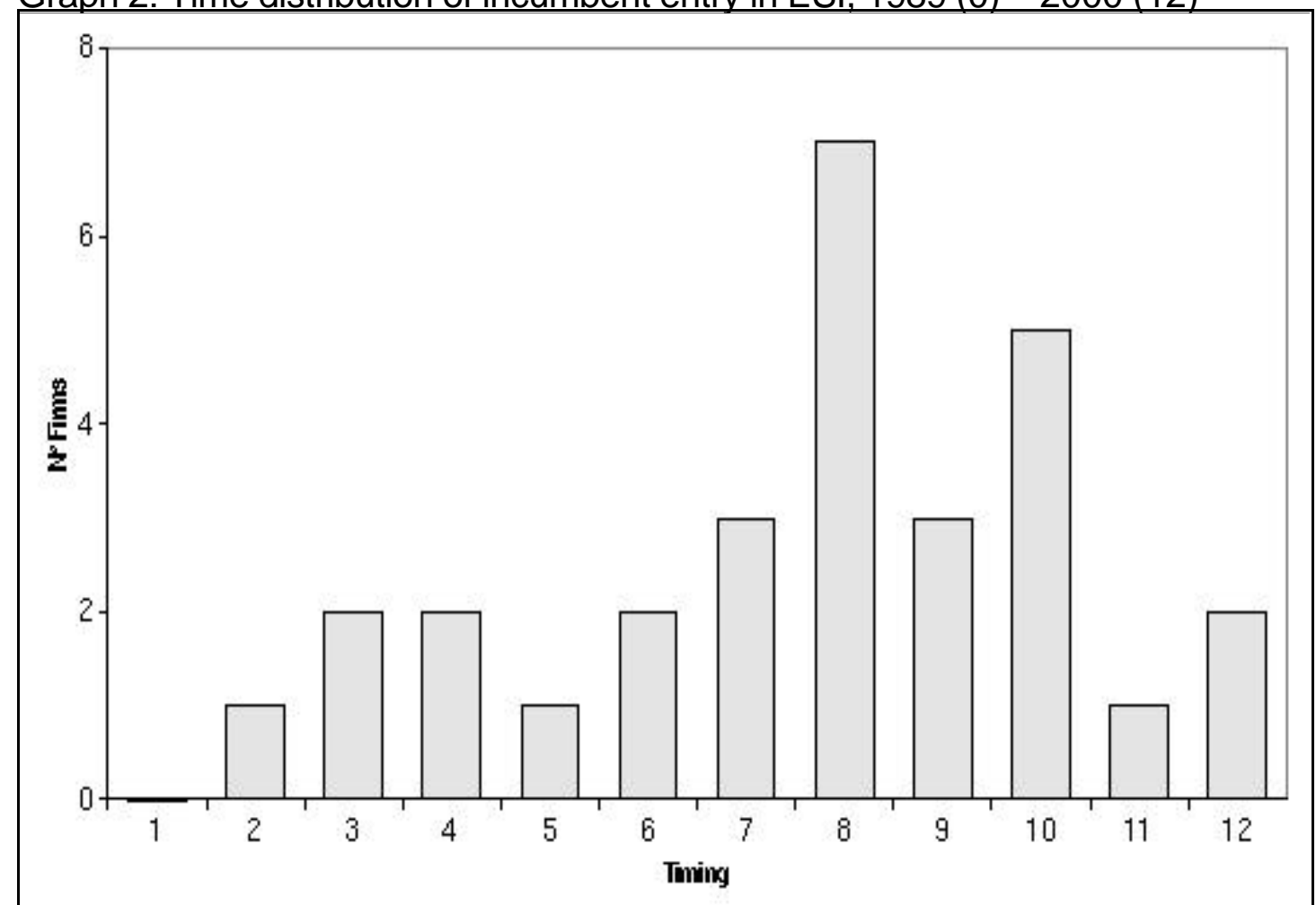

Source: Infotrac Business Source ASAP 
Graph 3: Growth rate of gross entry in ESI, 1990-2000

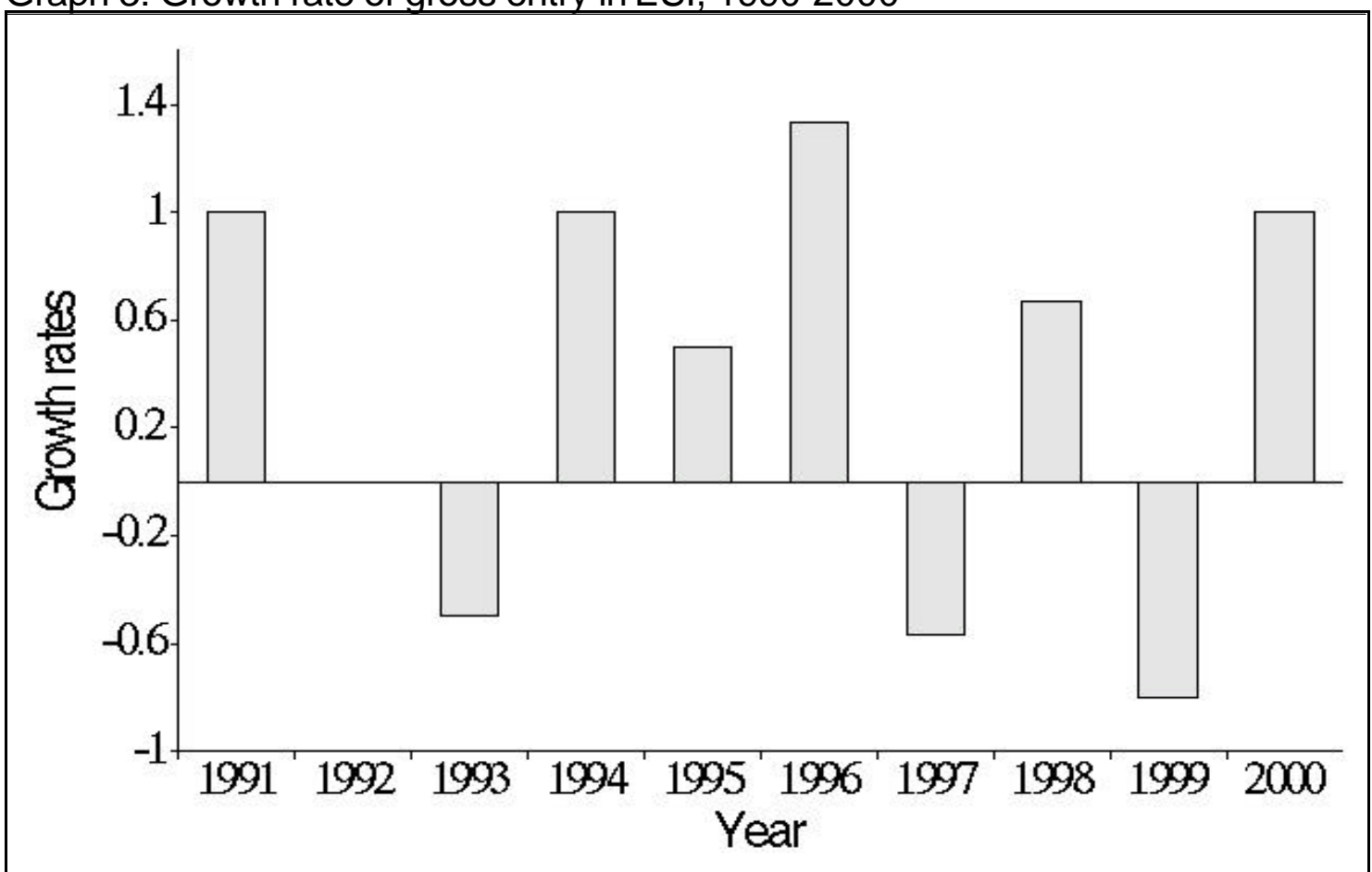

Source: Infotrac Business Source ASAP 